\title{
Proopiomelanocortin-derived Peptides Are Synthesized and Released by Human Keratinocytes
}

\author{
E. Schauer, * F. Trautinger, * A. Köck, * A. Schwarz, * R. Bhardwaj, * M. Simon, * J. C. Ansel, * T. Schwarz, * and T. A. Luger * \\ *Department of Dermatology and Ludwig Boltzmann Institute of Cell Biology and Immunobiology, University of Münster, D-48149, \\ Germany; and ${ }^{\ddagger}$ Dermatology Service, Veterans Affairs Medical Center, Department of Dermatology, Oregon Health Sciences University, \\ Portland, Oregon 97201
}

\begin{abstract}
Proopiomelanocortin (POMC), the precursor for melanotropic, corticotropic, and opioid peptides such as $\alpha$-melanocytestimulating hormone ( $\alpha$ MSH), ACTH, and other related peptides, was originally identified as a product of the pituitary gland. However, recent evidence shows that POMC products can also be produced by nonpituitary tissues. Because keratinocytes, the major constituent of the epidermis exhibit the capacity to release a variety of proinflammatory and immunomodulatory mediators, the present study was performed to investigate whether human keratinocytes are able to produce POMC-derived peptides. Supernatants of human normal keratinocytes and an epidermal carcinoma cell line (A431) contained significant levels of immunoreactive $\alpha \mathrm{MSH}$ and ACTH. Upon immuneprecipitation and size-exclusion chromatography, keratinocyte-derived $\alpha \mathrm{MSH}$ exhibited a molecular mass of $\sim 1 \mathrm{kD}$ and was biologically active as demonstrated in a tyrosinase bioassay. Northern blot analysis revealed the expression of POMC-specific transcripts $(1.3 \mathrm{~kb})$ in both normal keratinocytes and A431 cells. The production of $\alpha \mathrm{MSH}$ and ACTH could be significantly upregulated both at the protein and mRNA level upon treatment with phorbol myristate acetate, ultraviolet light, or interleukin 1 . These data provide first evidence that human keratinocytes produce POMC-derived peptides such as $\alpha$ MSH and ACTH. Because POMC-derived peptides recently have been recognized as potent immunomodulatory mediators, their presence in the epidermis may have a major impact on the skin immune system. (J. Clin. Invest. 1994. 93:2258-2262.) Key words: epidermis • proopiomelanocortin • melanocyte-stimulating hormone $\bullet$ inflammation $\bullet$ cytokine
\end{abstract}

\section{Introduction}

Alpha-melanocyte-stimulating hormone $(\alpha \mathrm{MSH})^{1}$ is a 13amino acid peptide named originally for its ability to stimulate skin pigmentation in amphibians (1). It is generated by posttranslational enzymatic cleavage of the 241 -amino acid precur-

1. Abbreviations used in this paper: HNK, human normal keratinocytes; MSH, melanocyte-stimulating hormone; POMC, proopiomelanocortin; rh, recombinant human.

Address correspondence to Thomas A. Luger, Hautklinik Universität Münster, Von Esmarch Strasse 56, D-48149 Münster, Germany.

Received for publication 10 May 1993 and in revised form 14 October 1993.

J. Clin. Invest.

(C) The American Society for Clinical Investigation, Inc.

$0021-9738 / 94 / 05 / 2258 / 05 \quad \$ 2.00$

Volume 93, May 1994, 2258-2262 sor molecule proopiomelanocortin (POMC) yielding corticotropic, melanotropic, and opioid peptides such as ACTH, $\beta$-lipotropin, $\beta \mathrm{MSH}, \gamma \mathrm{MSH}$ and $\beta$-endorphin (2). POMC was primarily identified in the pituitary gland, but the production of POMC-derived peptides is not confined to this organ, because several recent studies have demonstrated POMC peptides in various other tissues (3-6). In addition, it was possible to isolate $\alpha \mathrm{MSH}$ in considerable quantities from the skin of various species, including humans (7). Although the origin of $\alpha \mathrm{MSH}$ found within the skin has not been determined, it is unlikely to be pituitary derived, because the cutaneous MSH content showed little change after hypophysectomy in rats (1).

The melanocyte within the epidermis appears to be one of the primary targets for the melanotropic hormone $\alpha \mathrm{MSH}$ (8). However, several POMC-derived peptides, including $\alpha \mathrm{MSH}$ and ACTH, additionally have been recognized as being immunomodulatory mediators $(3,9)$. Keratinocytes, the major constituents of the epidermis, are well known to produce a variety of immunoregulatory cytokines (10). Therefore, in the present study, human keratinocytes were investigated for their ability to produce POMC-derived peptides such as $\alpha \mathrm{MSH}$ or ACTH.

\section{Methods}

Cell culture. The human epidermoid carcinoma cell line A431 (CRL 1555; American Type Culture Collection, Rockville, MD) was maintained in monolayer cultures at $37^{\circ} \mathrm{C}$ in a humidified atmosphere containing $5 \% \mathrm{CO}_{2}$. Long-term culture of normal human foreskin keratinocytes (HNK) were obtained as previously described and maintained in MCDB153 media (11).

To investigate the kinetics of factor production, HNK or A431 cells were plated at a density of $1 \times 10^{6} / \mathrm{ml}$ in petri dishes and supernatants were harvested at different time points $(24,48$, and $72 \mathrm{~h})$, centrifuged at $1,000 \mathrm{~g}$, and stored at $-70^{\circ} \mathrm{C}$. Supernatants derived from $\mathrm{HNK}$ were enriched 10 times using a C18-plus column (Millipore Corp., Bedford, MA). To stimulate POMC-derived peptide production, cells were treated with phorbol myristate acetate (PMA; Sigma Chemical Co., St. Louis, MO) or different cytokines: recombinant human (rh) IL-2 and rhIL-6 (Collaborative Research, Bedford, MA), rhIL-1 $\beta$ and rhGMCSF (Boehringer Mannheim, Germany), rhIFN $\gamma$ (Ernst Boehringer Institute, Vienna, Austria), rhTNF $\alpha$ (Endogen Inc., Boston, MA) and rh transforming growth factor $\beta$ (British Biotechnology, Oxford, UK). In some experiments, cells were exposed to ultraviolet light (UVB FS20 bulbs; Westinghouse Electric Corp., Pittsburgh, PA), with doses ranging from 40 to $120 \mathrm{~J} / \mathrm{m}^{2}(12)$. During UV irradiation, culture medium was replaced by PBS (12).

Assay for $\alpha M S H$ and ACTH. For the detection of $\alpha \mathrm{MSH}$ in epidermal cell-derived supernatants, an $\alpha$ MSH-RIA was used (Milab Corp., Malmö, Sweden ). This assay is sensitive to $5 \mathrm{pg} / \mathrm{ml}$ and does not crossreact with other POMC-derived peptides such as des-amido- $\alpha \mathrm{MSH}$, $\beta \mathrm{MSH}, \gamma \mathrm{MSH}, \mathrm{ACTH} 1-13$, ACTH 1-24, and ACTH 1-39 (13). To determine if $\alpha \mathrm{MSH}$ detected in epidermal cell-derived supernatants is biologically active, a tyrosinase assay was used as described (14). Briefly, B16 mouse melanoma cells were grown in 24-well plates, sub- 
sequently medium containing $0.2 \mu \mathrm{Ci}\left[3^{\prime}, 5^{\prime}-{ }^{3} \mathrm{H}\right]-\mathrm{L}-$ tyrosine and serial dilutions of epidermal cell-derived supernatants to be tested were added. After $48 \mathrm{~h}$ of incubation, medium was removed, treated with activated charcoal, centrifuged, and finally free ${ }^{3} \mathrm{H}$ generated during the conversion from tyrosine to dopa was counted in a liquid scintillation counter (LKB, Bromma, Sweden).

For the detection of ACTH, an RIA (Allegro-HS-ACTH; Nichols Institute, San Juan, CA ) was used. This test is sensitive to $15 \mathrm{pg} / \mathrm{ml}$ and does not cross-react with other POMC-derived peptides such as $\alpha \mathrm{MSH}$, $\beta \mathrm{MSH}$, and $\beta$-endorphin. The statistical significance was calculated by using the Student's $t$ test.

HPLC. Supernatants derived from A431 cells were enriched as described above and subjected to a size-exclusion column (bio sil TSK $125,300 \times 7.5 \mathrm{~mm}$; Bio-Rad Laboratories, Inc., Richmond, CA ). Elution was carried out with PBS ( $\mathrm{pH} 7.2$ ) at a flow rate of $1.0 \mathrm{ml} / \mathrm{min}$. Column fractions were filter sterilized and stored frozen at $-70^{\circ} \mathrm{C}$ before being tested (11).

Immuneprecipitation of metabolically labeled $\alpha M S H$. A431 cells $\left(2 \times 10^{7}\right)$ were incubated with or without PMA $(10 \mathrm{ng} / \mathrm{ml})$ in serumfree Eagle's MEM (Gibco, BRL, Paisley, Scotland). After $18 \mathrm{~h}$ of incubation, the supernatant was replaced by medium containing ${ }^{14} \mathrm{C}$-labeled amino acid mixture $(12.5 \mu \mathrm{Ci} / \mathrm{ml}$; Amersham Buchler, Braunschweig, Germany) and incubation was continued for a further $48 \mathrm{~h}$. Subsequently, supernatant $\alpha \mathrm{MSH}$ was immunoprecipitated with the same $\alpha \mathrm{MSH}$ antibody that was used for the RIA (Milab Corp.) (15). Proteins were solubilized under denaturing conditions and subsequently subjected to electrophoresis (15\% SDS-PAGE) (16). The proteins thus separated were visualized by autoradiography (Kodak XOmatic AR; $-70^{\circ} \mathrm{C}$ for $2 \mathrm{wk}$ ).

Northern blot analysis. For the detection of POMC, a 0.9-kb Hind III cDNA probe kindly provided by J. Clements (South Melbourne, Victoria, Australia) was used. Northern blot analysis was performed as previously described (11). Cultured HNK $\left(3 \times 10^{7}\right.$ cells) or A431 ( 1 $\times 10^{7}$ cells) were detached by treatment with ice-cold PBS. Total cellular RNA was isolated by $4 \mathrm{M}$ guanidium isothiocyanate/caesium chloride ultracentrifugation and quantitated by reading at $260 \mathrm{~nm} .30 \mu \mathrm{g}$ of RNA was electrophoresed on $1 \%$ agarose/2.2 $\mathrm{M}$ formaldehyde gels followed by transfer to nitrocellulose (Schleicher \& Schuell, Keene, $\mathrm{NH}$ ) and prehybridized overnight. The cDNA POMC probe was ${ }^{32} \mathrm{P}-$ radiolabeled by the random priming method, hybridized over night, and washed under stringent washing conditions (17). Equivalent loading and uniformity were assured by ethidium bromide staining of the gels before and after Northern transfer. In addition, equivalent amounts of RNA were verified by hybridizing the blot with a ${ }^{32} \mathrm{P}$-labeled cDNA probe $(1.0 \mathrm{~kb})$ for cyclophylin (1B15), generously provided by J. Douglass (Oregon Health Sciences University, Portland, OR). Autoradiography was carried out at $-70^{\circ} \mathrm{C}$ using Kodak XOmatic AR films.

\section{Results}

To investigate whether keratinocytes produce $\alpha \mathrm{MSH}$, HNK were cultured in supplemented MCDB153 medium without pituitary extract. Conditioned media were harvested after 24, 48 , or $72 \mathrm{~h}$, enriched 10 times, and tested for $\alpha$ MSH by RIA. Unconcentrated supernatants obtained from HNK did not contain detectable $\alpha \mathrm{MSH}$ reactivity, whereas concentrated HNK supernatants exhibited yet low, though unequivocally detectable amounts of immunoreactive $\alpha \mathrm{MSH}$. Treatment of HNK with $10 \mathrm{ng} / \mathrm{ml}$ PMA resulted in a significant induction of $\alpha \mathrm{MSH}$ release, with highest yields accumulating after $72 \mathrm{~h}$ of culture ( Table I). In addition to HNK, the human epidermoid carcinoma cell line A431 demonstrated $\alpha \mathrm{MSH}$ production with similar kinetics of release and inducibility by PMA ( Table I).

Keratinocytes bear receptors for a variety of cytokines (18), thus the effects of IL- $1 \beta$, IL-2, IL-6, TNF $\alpha$, GM-CSF, transforming growth factor $\beta$, or IFN $\gamma$ on the release of $\alpha \mathrm{MSH}$ were tested. The addition of IL- $1 \beta$ to cultured A431 cells resulted in a dose-dependent induction of $\alpha \mathrm{MSH}$ production. Maximum increase was obtained with $10 \mathrm{U} / \mathrm{ml} \mathrm{IL-1} \beta$ after $3 \mathrm{~d}$ of culture (Table I). In contrast, all the other cytokines tested did not alter $\alpha \mathrm{MSH}$ production by A431 cells (data not shown).

Because $\alpha \mathrm{MSH}$ induces pigmentation in many mammalians, the effect of UVB light on the release of $\alpha \mathrm{MSH}$ by A431 cells was tested. Cells were irradiated with UVB light $(120 \mathrm{~J} /$ $\mathrm{m}^{2}$ ) and supernatants were harvested after 24,48 , or $72 \mathrm{~h}$. Supernatants obtained 48 or 72 h after UVB exposure contained significantly elevated levels of $\alpha \mathrm{MSH}$ ( Table I). If cells were irradiated with $<120 \mathrm{~J} / \mathrm{m}^{2}, \alpha \mathrm{MSH}$ production by A431 cells was not observed (data not shown). Doses of UV exceeding $120 \mathrm{~J} / \mathrm{m}^{2}$ were not used in these experiments because this can result in significant cell damage (19).

To further characterize epidermal cell-derived $\alpha \mathrm{MSH}$, the capacity of an $\alpha \mathrm{MSH}$ antibody to precipitate biosynthetically labeled $\alpha \mathrm{MSH}$ was investigated. A431 cells were cultured with or without $10 \mathrm{ng} / \mathrm{ml}$ PMA and incubated with a ${ }^{14} \mathrm{C}$-labeled amino acid mixture. Subsequently, supernatants were collected, the presence of $\alpha \mathrm{MSH}$ released was analyzed by immunoprecipitation with anti- $\alpha \mathrm{MSH}$, and the precipitates thus obtained were separated by SDS-PAGE carried out under reducing conditions. The antibody precipitated one major protein migrating with a relative molecular mass of $1 \mathrm{kD}$, which corresponds to the molecular weight of $\alpha \mathrm{MSH}$. Moreover, the specific band detected in PMA-treated supernatants was significantly enhanced compared with that found in untreated cells (Fig. 1).

To investigate whether epidermal cell-derived $\alpha \mathrm{MSH}$ is biologically active, A431 supernatants obtained after $72 \mathrm{~h}$ were subjected to HPLC gel filtration before analysis in a tyrosinase bioassay. Tyrosinase-inducing activity eluted in fractions of the low molecular weight range, which corresponds to the molecular weight of $\alpha \mathrm{MSH}$ (Fig. 2).

Because ACTH is another major cleavage product of POMC, the ability of A431 cells to produce ACTH was evaluated using an $\mathrm{ACTH}$-specific immunoradiometric assay. Significant amounts of ACTH were detected in A431-conditioned medium. The kinetics and inducibility of ACTH in these cells was similar to those observed with epidermal cell-derived $\alpha \mathrm{MSH}$. Like $\alpha \mathrm{MSH}$, the maximum ACTH production by A431 cells was detected $72 \mathrm{~h}$ after stimulation with PMA ( Table I).

To determine whether POMC-specific mRNA is expressed in human epidermal cells, Northern blot analysis was performed using a human POMC cDNA probe. In A431 cells small amounts of POMC mRNA were found to be expressed constitutively and were upregulated significantly at $4 \mathrm{~h}$ after treatment with $10 \mathrm{ng} / \mathrm{ml}$ PMA and $10 \mathrm{U} / \mathrm{ml} \mathrm{IL-1 \beta}$ (Fig. 3). Specific transcripts with a size of $1.3 \mathrm{~kb}$ were also detected in RNA extracted from HNK after stimulation with $10 \mathrm{U} / \mathrm{ml}$ IL- $1 \beta$ for $4 \mathrm{~h}$, while constitutive expression was under detection limit (Fig. 4).

\section{Discussion}

The present study for the first time provides evidence that normal human keratinocytes and a keratinocyte cell line produce POMC-derived peptides such as $\alpha \mathrm{MSH}$ and ACTH. Release of 
Table I.

\begin{tabular}{|c|c|c|c|c|c|c|c|}
\hline & \multirow[b]{2}{*}{ Incubation } & \multicolumn{4}{|c|}{$\alpha$ MSH } & \multicolumn{2}{|c|}{ ACTH } \\
\hline & & Co & PMA & IL-1 & UVB & Co & PMA \\
\hline & $h$ & \multicolumn{4}{|c|}{$p g / m l$} & \multicolumn{2}{|c|}{$p g / m l$} \\
\hline \multirow[t]{3}{*}{ A431 } & 24 & $11.6 \pm 1.1$ & $14.8 \pm 1.1$ & $10.0 \pm 1.7$ & $22.1 \pm 1.1$ & $23.7 \pm 1.0$ & $27.3 \pm 1.2$ \\
\hline & 48 & $18.5 \pm 3.0$ & $50.2 \pm 7.6^{*}$ & $30.7 \pm 3.2$ & $43.7 \pm 3.1^{*}$ & $31.2 \pm 3.8$ & $120 \pm 9.1^{*}$ \\
\hline & 72 & $37.5 \pm 5.2$ & $105.4 \pm 12.5^{*}$ & $90.7 \pm 7.6^{*}$ & $57.2 \pm 7.1^{*}$ & $92.3 \pm 7.1$ & $230 \pm 14.7^{*}$ \\
\hline \multirow[t]{3}{*}{ HNK } & 24 & $29.3 \pm 1.4$ & $23.6 \pm 2.1$ & $\mathrm{NT}^{*}$ & NT & NT & NT \\
\hline & 48 & $36.6 \pm 0.7$ & $56.3 \pm 1.5^{*}$ & NT & NT & NT & NT \\
\hline & 72 & $41.1 \pm 1.41$ & $76.6 \pm 3.3$ & NT & NT & NT & NT \\
\hline
\end{tabular}

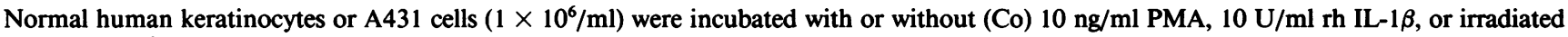
with $120 \mathrm{~J} / \mathrm{m}^{2} \mathrm{UVB}$ and cultured for 24,48 , or $72 \mathrm{~h}$. Supernatants derived from HNK were enriched 10 times as described in Methods. Both A431 supernatants and concentrated HNK supernatants were tested in the $\alpha$ MSH-RIA and the ACTH immunoradiometric assay. Results are expressed as means $\pm \mathrm{SE} \mathrm{pg} / \mathrm{ml}$ of three different experiments. Statistical significance of $\alpha \mathrm{MSH}$ or ACTH induction in comparison to the unstimulated control was calculated using the Student's $t$ test. ${ }^{*} P<0.001$. NT, not tested.

$\alpha \mathrm{MSH}$ by keratinocytes was primarily detected by immunoassays yet the use of a tyrosinase bioassay indicated keratinocytederived $\alpha \mathrm{MSH}$ also to be biologically active. Low levels of $\alpha \mathrm{MSH}$ and ACTH are constitutively generated by keratinocytes, which are significantly increased by various stimuli.

Recently, POMC mRNA transcripts in normal human nonpituitary tissues were found to be truncated molecules lacking the $5^{\prime}$ end of the coding region of the mRNA, explaining the low peptide content in comparison to the amount of POMC mRNA expressed (2). Northern blot analysis has shown that HNK and A431 cells express POMC mRNA with a size of $1.3 \mathrm{~kb}$, which is similar to the full-size transcript reported in pituitary tissue.

The fact that $\alpha \mathrm{MSH}$ is produced by keratinocytes may have particular biological relevance, because $\alpha$ MSH can stimulate cutaneous pigment cells from various species, including rodents, via cAMP-dependent mechanisms (20). In humans, whether $\alpha \mathrm{MSH}$ regulates pigmentary responses is still a contro-

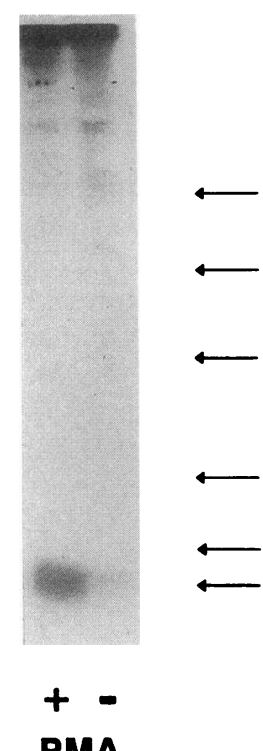

46

30

21

14.3

Figure 1. SDS-PAGE of metaboli3.4 cally labeled and immunoprecipi2.3 tated $\alpha \mathrm{MSH}$. Autoradiogram of immunoprecipitated peptides with anti- $\alpha$ MSH from supernatants of $2 \times 10^{7}$ A431 cells cultured with or without $10 \mathrm{ng} / \mathrm{ml}$ PMA. Molecular mass markers as indicated in $\mathrm{kD}$. versial issue (21). However, generalized skin hyperpigmentation has been reported upon $\alpha \mathrm{MSH}$ hypersecretion by the pituitary (22), and humans injected with $\alpha \mathrm{MSH}$ or a synthetic analogue of $\alpha \mathrm{MSH}$ showed increased skin darkening $(23,24)$. Because the present study demonstrates that the production of $\alpha \mathrm{MSH}$ by human keratinocytes is induced significantly by UVB radiation, a role of keratinocyte-derived $\alpha \mathrm{MSH}$ in UVinduced pigmentation is suggestive.

In addition, POMC peptides have been demonstrated to modulate immune and inflammatory reactions (3). Accordingly, $\alpha$ MSH blocks particular functions of IL-1, i.e., induction of thymocyte proliferation and $\mathrm{PGE}_{2}$ release by fibroblasts (25). The ability of either IL-1 or TNF $\alpha$ to cause fever, leukocytosis, and enhancement of plasma acute phase proteins also was found to be inhibited by the simultaneous administration of $\alpha \mathrm{MSH}$ (26). Moreover, $\alpha \mathrm{MSH}$ reversed the depressive influences of IL-1 or TNF $\alpha$ on the effector phase of contact hypersensitivity in animals (26). There is even more evidence for the

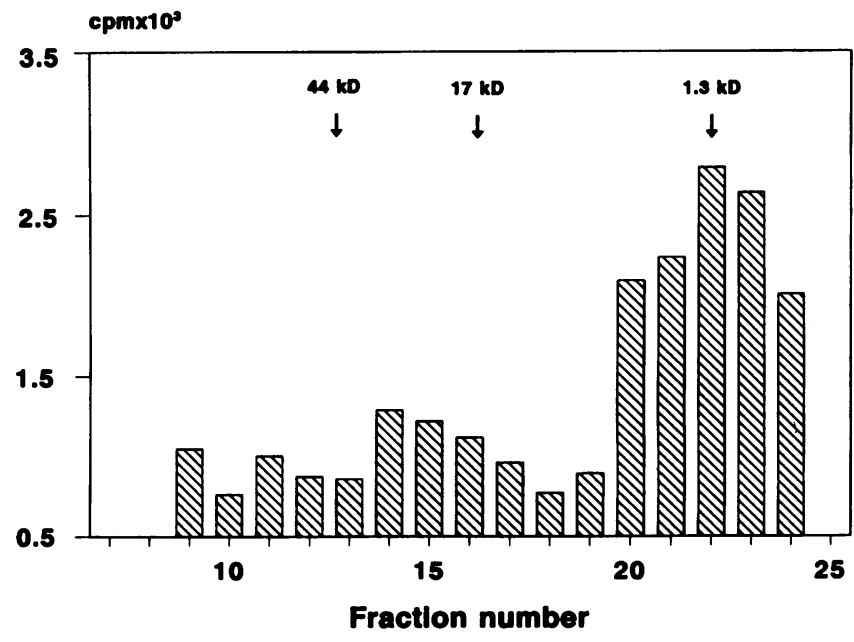

Figure 2. A431 cells $\left(1 \times 10^{6} / \mathrm{ml}\right)$ were stimulated with $10 \mathrm{ng} / \mathrm{ml}$ PMA, cultured for $72 \mathrm{~h}$ and concentrated. Subsequently, HPLC gel filtration (bio sil TSK 125) was performed and column fractions were tested for $\alpha \mathrm{MSH}$ activity in the tyrosinase bioassay as described in Methods. Results are expressed as mean cpm of triplicates. SE was within $10 \%$. 


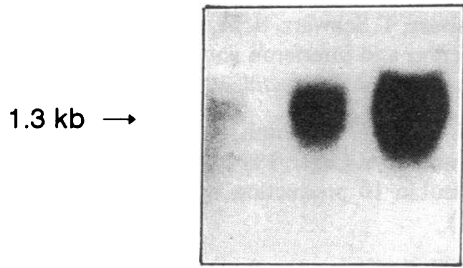

IL-1 PMA
Figure 3. POMC expression in A431 cells. A431 ( 1 $\times 10^{7}$ ) cells were left untreated or stimulated with $10 \mathrm{ng} / \mathrm{ml}$ PMA or $10 \mathrm{U} / \mathrm{ml}$ IL-1. RNA was extracted $4 \mathrm{~h}$ after stimulation and hybridized with a cDNA probe encoding for POMC. concert with epidermal cell-derived cytokines and eicosanoids, may function as part of the skin immune system.

\section{Acknowledgments}

We acknowledge the expert secretarial assistance of M. L. Hülsmann. This work was supported by grants from the Deutsche Forschungsgemeinschaft DFG Lu 443/1-1 and the Volkswagenwerke AZ:I/67-420. immunomodulatory ability of POMC-derived peptides, because it was shown that $\alpha \mathrm{MSH}$ inhibits the production of IFN $\gamma$ by PBMC (27). In contrast, the synthesis of IL-10 was found to be upregulated by $\alpha \mathrm{MSH}$ (28), and both $\alpha \mathrm{MSH}$ as well as ACTH seem to be able to modulate IL-4- and anti-CD40driven release of IgE by PBMC. ACTH at physiological concentrations increased IgE synthesis, whereas higher doses of ACTH strongly inhibited IgE synthesis by PBMC (27). Therefore, POMC peptides may play a role in the pathogenesis of allergic diseases and may represent the postulated neuroendocrine arm in diseases such as atopic dermatitis.

These findings raise new and important aspects concerning cutaneous inflammation. Because $\alpha \mathrm{MSH}$ can antagonize particular biological activities of the proinflammatory cytokine IL-1, it may play a crucial role in the downregulation of inflammatory reactions in the skin (26). To obtain more insights into these mechanisms, the signals influencing the release of $\alpha \mathrm{MSH}$ by keratinocytes need to be studied. In particular the influence of UV irradiation on the release of $\alpha \mathrm{MSH}$ by keratinocytes appears of relevance, because keratinocytes are the main target of UV light, which is known to cause local as well as systemic immunosuppression. Recently, it was found that epicutaneous application of $\alpha \mathrm{MSH}$ suppresses both the sensitization and elicitation limbs of the cutaneous immune response to potent contact sensitizers (29). UV light is well known to suppress the induction of contact hypersensitivity (30). Thus the UV-induced production of $\alpha \mathrm{MSH}$ by keratinocytes may be involved in mediating the suppressive effect on the epicutaneous sensitization response. This is in agreement with previous studies in which mediators released from keratinocytes inhibited contact hypersensitivity when injected intravenously into test animals (19). In summary, the present study demonstrates that human keratinocytes can release POMC-derived peptides, which, in

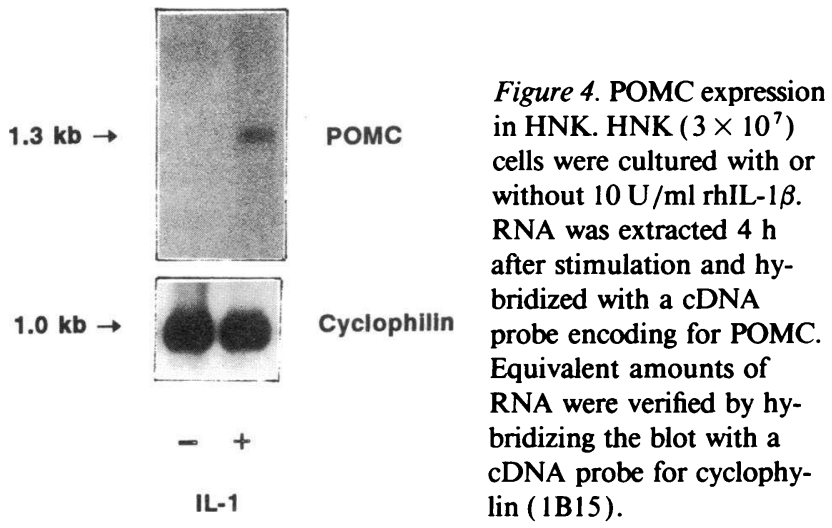

\section{References}

1. Eberle, A. N. 1988. The Melanotropins. Karger, Basel, Switzerland.

2. Burbach, J. P. H., and V. M. Wiegant. 1990. Gene expression, biosynthesis and processing of proopiomelanocortin peptides and vasopressin. In Neuropeptides: Basics and Perspectives. de Wied, editor. Elsevier, Amsterdam. 45-103.

3. Bateman, A., A. Singh, T. Kral, and S. Solomon. 1989. The immune-hypothalamic-pituitary-adrenal axis. Endocr. Rev. 10:92-112.

4. Tsong, S. D., D. Phillips, N. Halmi, A. S. Liotta, A. Margioris, C. W. Bardin, and D. T. Krieger. 1982. ACTH and beta-endorphin-related peptides are present in multiple sites in the reproductive tract of the male rat. Endocrinology. 110:2204-2206.

5. Lolait, S. J., J. A. Clements, A. J. Markwick, C. Cheng, M. McNally, A. I Smith, and J. W. Funder. 1986. Pro-opiomelanocortin messenger ribonucleic acid and posttranslational processing of beta endorphin in spleen macrophages. J. Clin. Invest. 77:1776-1779.

6. Oates, E. L., G. P. Allaway, G. R. Armstrong, R. A. Boyajian, J. H. Kehrl, and B. S. Prabhakar. 1988. Human lymphocytes produce pro-opiomelanocortin gene-related transcripts. Effects of lymphotropic viruses. J. Biol. Chem. 263:10041-10044.

7. Thody, A. J., K. Ridley, R. J. Penny, R. Chalmers, C. Fisher, and S. Shuster 1983. MSH peptides are present in mammalian skin. Peptides (NY). 4:813-816.

8. Nordlund, J. J., Z. A. Abdel Malek, R. E. Boissy, and L. A. Rheins. 1989. Pigment cell biology: an historical review. J. Invest. Dermatol. 92:53S-60S.

9. Brown, S. L., and J. E. Blalock. 1990. Neuroendocrine immune interactions. In Immunophysiology, the Role of Cells and Cytokines in Immunity and Inflammation. J. J. Oppenheim and E. M. Shevach, editors. Oxford University Press, Oxford, UK. 306-319.

10. Schwarz, T., and T. A. Luger. 1992. Pharmacology of cytokines in the skin. In Pharmacology of the Skin. H. Muhktar, editor. CRC Press, Boca Raton, FL. 283-314.

11. Kirnbauer, R., A. Kock, T. Schwarz, A. Urbanski, J. Krutmann, W. Borth, D. Damm, G. Shipley, J. C. Ansel, and T. A. Luger. 1989. IFN-beta 2, B cell differentiation factor 2 , or hybridoma growth factor (IL-6) is expressed and released by human epidermal cells and epidermoid carcinoma cell lines. $\mathrm{J}$. Immunol. 142:1922-1928.

12. Schwarz, T., A. Urbanska, F. Gschnait, and T. A. Luger. 1987. UV-irradiated epidermal cells produce a specific inhibitor of interleukin 1 activity. $J$. Immunol. 138:1457-1463.

13. Catania, A., L. Airaghi, M. G. Manfredi, M. C. Vivirito, F. Milazzo, J. M. Lipton, and C. Zanussi. 1993. Proopiomelanocortin-derived peptides and cytokines: relations in patients with acquired immunodeficiency syndrome. Clin. Immunol. Immunopathol. 66:73-79.

14. Pomeranz, S. H. 1966. The tyrosine hydroxylase activity of mammalian tyrosinase. J. Biol. Chem. 241:161-168.

15. Gieselmann, V., R. Pohlmann, A. Hasilik, and K. Figura. 1983. Biosynthesis and transport of cathepsin D in cultured human fibroblasts. J. Cell Biol. 97:1-7.

16. Laemmli, U. K. 1970. Cleavage of structural proteins during the assembly of the head of bacteriophage T4. Nature (Lond.). 227:680-683.

17. Feinberg, A. P., and P. A. Vogelstein. 1983. A technique for radiolabeling DNA restriction endonuclease fragments to high specific activity. Anal. Biochem. 132:6-13.

18. Kupper, T. 1990. The role of epidermal cytokines. In Immunophysiology, the role of Cells and Cytokines in Immunity and Inflammation. J. J. Oppenheim and E. M. Shevach, editors. Oxford University Press, New York. 285-305.

19. Schwarz, T., A. Urbanski, F. Gschnait, and T. A. Luger. 1986. Inhibition of the induction of contact hypersensitivity by a UV-mediated epidermal cytokine. J. Invest. Dermatol. 87:289-291.

20. Pawelek, J. M. 1990. Is human melanogenesis stimulated by cyclic AMP? J. Invest. Dermatol. 94:499-500.

21. Burchill, S. A., J. M. Marks, and A. J. Thody. 1990. Tyrosinase synthesis in different skin types and the effects of alpha-melanocyte-stimulating hormone and cyclic AMP. J. Invest. Dermatol. 95:558-561. 
22. Pears, R. S., R. T. Jung, W. Bartlett, M. C. K. Browning, K. Kenicer, and A. J. Thody. 1992. A case of skin hyperpigmentation due to alpha-MSH hypersecretion. Br. J. Dermatol. 126:286-289.

23. Lerner, A. B., and J. S. McGuire. 1961. The effect of alpha and beta melanocyte stimulating hormone on the skin colour of man. Nature (Lond.). 189:176-179.

24. Levine, N., S. N. Sheftel, T. Eytan, R. T. Dorr, M. E. Hadley, J. C. Weinrach, G. A. Ertl, K. Toth, D. L. McGee, and V. J. Hruby. 1991. Induction of skin tanning by subcutaneous administration of a potent synthetic melanotropin. JAMA (J. Am. Med. Assoc.). 266:2730-2736.

25. Cannon, J. G., J. B. Tatro, S. Reichlin, and C. A. Dinarello. 1986. Alpha melanocyte stimulating hormone inhibits immunostimulatory and inflammatory actions of interleukin 1. J. Immunol. 137:2232-2236.

26. Robertson, B., K. Dostal, and R. A. Daynes. 1988. Neuropeptide regulation of inflammatory and immunologic responses. The capacity of alpha-melanocyte-stimulating hormone to inhibit tumor necrosis factor and IL-1-inducible biologic responses. J. Immunol. 140:4300-4307.
27. Aebischer, I., E. Schauer, A. Schwarz, T. Schwarz, B. M. Stadler, and T. A. Luger. 1993. Regulation of IgE production and interferon gamma synthesis by proopiomelanocortin derived peptides. J. Invest. Dermatol. 100:574. (Abstr.)

28. Bhardwaj, R. S., A. Schwarz, Y. Aragane, M. Simon, A. Palmetshofer, H Riemann, M. Hartmeyer, T. Schwarz, and T. A. Luger. 1994. Alpha-melanocyte stimulating hormone augments interleukin 10 production by human $\mathrm{T}$ cells. Arch. Dermatol. Res. 286:229. (Abstr.)

29. Rheins, L. A., A. L. Cotleur, R. S. Kleier, W. B. Hoppenjans, D. N Sauder, and J. J. Nordlund. 1989. Alpha-melanocyte stimulating hormone modulates contact hypersensitivity responsiveness in C57 / BL6 mice. J. Invest. Dermatol. 93:511-517.

30. Jessup, J. M., N. Hanna, E. Palaszynski, and M. L. Kripke. 1978. Mechanisms of depressed reactivity to dinitrochlorobenzene and ultraviolet-induced tumors during ultraviolet carcinogenesis in BALB/c mice. Cell. Immunol. 38:105-115. 